\title{
LEKSIKON TINDAKAN YANG DIGUNAKAN OLEH PETANI KARET \\ DI DESA SIMPANG BABEKO \\ MUARA BUNGO JAMBI \\ (Sebuah Tinjauan Antropolinguistik)
}

\author{
Nasrul \\ E-mail: dosen02545@unpam.ac.id \\ Universitas Pamulang, Tangerang Selatan
}

\begin{abstract}
Abstrak
Pemakaian leksikon dalam kehidupan sehari-hari cukup melimpah dan dapat ditemukan dalam bidang kegiatan masyarakat. Leksikon tindakan merupakan salah satu bentuk yang dapat diamati dari bagian tindakan atau kegiatan masyarakat yang berkaitan dengan pekerjaannya dalam konsep tertentu. Pemakaian leksikon tindakan tersebut juga berkaitan pada bidang pertanian, khususnya pada petani karet. Petani karet memiliki komunitas besar di daerah agraria terkhusus pada daerah di salah satu desa di Kabupaten Bungo Provinsi Jambi yang memiliki kekayaan leksikon yang cukup beragam. Penelitian ini menggunakan tinjauan antropolinguisitik dengan penelitian yag bersifat deskriptif kualitatif. Tujuan penelitian ini 1) mendeskripsikan bentuk leksikon tindakan, 2) mendeskripsikan makna leksikon tindakan. Hasil penelitian menunjukkan terdapat 16 (enam belas) bentuk leksikon yang berkaitan dengan tindakan yang digunakan oleh petani karet. Dari analisis data didapatkan lima jenis makna tindakan yang berkaitan dengan tindakan aktivitas petani karet yaitu 1) tindakan mengambil, 2) tindakan membersihkan, 3) tindakan memberi, 4) tindakan mengambil, dan 5) tindakan berpindah tempat.
\end{abstract}

Kata kunci: leksikon, leksikon tindakan, antropolinguistik, petani karet

\section{Pendahuluan}

Dalam kehidupan masyarakat Indonesia memiliki banyak sekali bidang pekerjaan. Ada yang bergerak di bidang jasa, bidang pertanian, perkebunan maupun bidang perikanan. Hal ini tidak disangkal karena Indonesia terletak di daerah yang memungkinkan bidang-bidang pekerjaan tersebut dilakukan.

Desa Simpang Babeko terletak di Kabupaten Bungo Provinsi Jambi yang mayoritas penduduknya memiliki pekerjaan sebagai petani karet maupun petani kelapa sawit. Desa ini terletak sepanjang jalan lintas provinsi Jambi yang sudah ramai masyarakatnya, tercatat ada sekitar $2000 \mathrm{KK}$ yang mendiami daerah ini (data Desa Simpang Babeko, 2019). Masyarakatnya terdiri dari pendatang 
maupun pribumi asli yang telah mulai mendiami daerah tersebut. Untuk masyakat pendatang berasal dari daerah Jawa, daerah Palembang, Sumatera Barat maupun daerah lain. Untuk itu, tidak disangkal bahwa Desa Simpang Babeko telah mengalami percampuran berbagai budaya yang saling menyatu dan saling keterkaitan.

Penggunaan bahasa dalam kehidupan sehari-hari cukup beragam, terutama penggunaan bahasa yang berkaitan dengan kosa kata yang berkaitan dengan bidang pekerjaan. Dalam penelitian ini mencoba untuk melihat penggunaan leksikon dalam bidang pekerjaan tertentu yang dikhususkan pada bidang pertanian karet di daerah di Jambi. Istilah leksikon dalam arti lain berupa kata-kata atau perbendaharaan kata (Chaer, 2007; Yusuf, 1995). Lebih lanjut lagi, Kridalaksana (2001) mendefinisikan sebagai (1) komponen bahasa yang memuat semua informasi tentang makna dan pemakaian kata dalam bahasa. (2) Kekayaan kata yang dimiliki seseorang pembicara, penulis, atau kosakata, atau perbendaharaan kata. (3) Daftar kata yang disusun seperti kamus, tetapi dengan penjelasan singkat dan praktis. Berdasarkan pengamatan dan penelitian di lapangan, terdapat banyak leksikon yang digunakan oleh petani karet di Desa Simpang Babeko Muara Bungo Jambi. Leksikon tersebut tentu memiliki keterkaitan dengan kehidupan sosial maupun kehidupan budaya masyarakatnya.

Penggunaan leksikon serta penciptaan suatu istilah yang berkaitan dengan konsep maupun suatu hal dalam tindakan masyarakat petani karet tentu memiliki suatu alasan. Peneliti mencoba untuk melihat dan meneliti hubungan serta keterkaitan antara leksikon tersebut dengan masyakaratnya, dengan suatu pendekatan teori antropolinguistik.

Penelitian terkait kajian antropolinguistik sudah banyak dilakukan para peneliti di Indonesia. Namun kajian secara khusus yang membahas mengenai leksikon tindakan yang berkaitan dengan aktivitas petani karet terkhusus pada daerah Desa Simpang Babeko Kabupaten Bungo belum ada yang membahas. Berikut penjelaskan singkat beberapa penelitian yang relevan dengan penelitian ini. Sebagai contoh penelitian yang dilakukan oleh Sitinjak (2018) dengan judul "Leksikon Verbal dan Umpasa dalam Tari Tortor Sawan: Kajian 
Antropolinguistik" yang menjelaskan penggunaan leksikon tindakan dan umpasa dalam tari Tortor Sawan; penelitian selanjutnya oleh Kusumawati (2016) dengan judul "Leksikon Budaya dalam Ungkapan Peribahasa Sunda (Kajian Antropolinguistik)" yang mendeskripsikan beberapa leksikon budaya yang dikhususkan pada peribahasa Sunda.

Dalam penelitian ini akan menggambarkan penggunaan leksikon yang digunakan oleh petani karet. Adapun permasalahan dasar yang ingin diungkap dalam penelitian 1) mendeskripsikan bentuk-bentuk leksikon tindakan yang digunakan oleh masyarakat petani karet di Desa Simpang Babeko Muara Bungo Jambi, 2) mendeskripsikan makna leksikon tindakan yang digunakan oleh masyarakat pertani karet di Desa Simpang Babeko Muara Bungo Jambi.

\section{Metode Penelitian}

Penelitian deskriptif tidak terlepas dari cara penelitian yang menuntut untuk mendeskripsikan data secara gamblang, apa adanya. Selanjutnya hasil temuan dari penelitian tersebut harus menjawab pertanyaan dari serangkaian permasalahan yang ditemukan di lapangan dengan sifatnya kualitatif. Adapun sumber data yang digunakan dalam penelitian ini adalah leksikon-leksikon tindakan atau leksikon-leksikon bermakna tindakan/ aktivitas petani karet di Desa Simpang Babeko Kec. Bathin II Babeko, Kab.Bungo, Prov. Jambi. Data leksikon tersebut didapat dari pengumpulan dari beberapa desa di wilayah Simpang Babeko, yakni Dusun Nyiur Gading, Desa Simpang Babeko, Dusun Sungai Kayu Batu. Untuk menjaring data, diperlukan masing-masing 2 (dua) informan dalam tiap-tiap daerah. Data diambil selama 2 bulan dari bulan Oktober 2020-Desember 2020. Pemilihan Desa Simpang Babeko sebagai sumber penelitian ini didasari pada mayoritas penduduk desa tersebut adalah petani karet. Selain itu, adanya percampuran masyarakat antara pendatang dan masyarakat asli, yang tentu akan mempengaruhi dalam bidang sosial, masyarakat maupun bidang lain.

Dalam penelitian ini menggunakan tiga tahap yaitu pada 1) tahap penyedian data, 2) tahap analisis data, 3) tahap penyediaan hasil analisis data. 


\section{1) Metode dan Teknik Penyediaan data}

Adapun pada tahapan ini menggunakan metode simak (Sudaryanto, 1988). Salah satu tindakan dalam penjaringan data dengan menyimak pengunaan bahasa. Teknik yang digunakan teknik cakap. Untuk mendukung teknik tersebut diperlukan pula teknik lain yaitu teknik catat dan teknik rekam (dengan alat recording).

\section{2) Metode dan Teknik Analisis Data}

Adapun dalam tahap ini menggunakan metode padan (Sudaryanto, 1993). Tujuan utama dalam penggunakan metode ini adalah analisis data berupa leksikon merupakan data kebahasaan yang perlu dihubungkan diluar bahasa guna mengetahui unsur-unsur antropolinguistik yang berkaitan dengan masyarak pemilik bahasa tersebut. Langkah selanjutnya menggunakan teknik Pilah Unsur Penentu (PUP) yang alat penentunya adalah daya pilah mental yang dimiliki peneliti (Sudaryanto, 1993). Teknik lanjutan menggunakan teknik Pilah Referensial serta menggunakan teknik Banding Menyamakan Hal Pokok yaitu menyamakan hal pokok pada bentuk leksikon dan bentuk usur-unsur antropolinguistik.

\section{2) Metode dan Teknik Penyajian Analisis Data}

Dalam tahap ini, cukup menggunakan perumusan informal dan formal (Sudaryanto, 1993). Secara informal menggunakan perumusan kata-kata biasa. Analisis data secara formal digunakan untuk menunjang perumusan informal yaitu menguraikan data dengan menggunakan tabel-tabel, maupun grafik maupun bagan. Penyajian analisis data penelitian berkaitan dengan leksikon yang digunakan untuk menjelaskan hal 'tindakan' yang digunakan oleh petani karet di Desa Simpang Babeko Kabupaten Bungo Jambi.

\section{Hasil Penelitian dan Pembahasan}

Data dalam penelitian ini terkait leksikon tindakan yang digunakan petani karet, ditemukan sebanyak 16 (enam belas) buah leksikon yang mengandung unsur budaya masyarakat. Data ini dibagi atas tiga variabel yakni berkaitan 
dengan 1) Tindakan Mengambil, 2) Tindakan Membersihkan, 3) Tindakan Memberi, 4) Tindakan Mengambil, dan 5) Tindakan Berpindah Tempat

\section{1) Tindakan Mengambil}

Leksikon tindakan yang mengandung makna mengambil ditemukan sebanyak 8 (delapan) leksikon. Leksikon tersebut mengacu pada tindakan atau aktivitas yang dilakukan oleh petani karet disaat mereka melaksanakan rutitinitasnya.

\section{leksikon mupul}

Leksikon mupul berasal dari kata kumpul, perubahan kata yang dipengaruhi oleh bahasa Jawa. Leksikon ini biasa digunakan oleh masyarakat ketika mereka akan melakukan pengambilan getah karet secara rutin setiap hari. Aktivitas mupul mengacu pada kegiatannya. Leksikon mupul biasa digunakan oleh masyarakat Jawa yang terletak di Dusun Nyiur Gading dan Dusun Sungai Kayu Batu. Dua desa ini ditemukan leksikon ini dikarenakan masyarakatnya cenderung banyak orang yang berasal dari Jawa atau perantau dari tanah Jawa.

\section{leksikon ngudun}

Leksikon ngudun berasal dari gabungan dua afiks yaitu prefiks $N+k u d u n$. Kudun memiliki arti getah batang karet yang sudah membeku yang berada di tempat penampungan yang terbuat dari tempurung kelapa maupun plastik. Kudun merupakan getah yang sudah beku, biasanya getah yang sudah lebih dari satu hari. Leksikon ngudun ini memiliki makna yang hampir sama dengan mupul, namun bedanya adalah leksikon tersebut biasanya digunakan oleh masyarakat pribumi. Daerah yang biasa menggunakan leksikon ini yaitu Desa Simpang Babeko.

\section{leksikon motong}

Leksikon motong berasal dari kata potong yang mengalami proses afiksasi dengan meN+potong ->motong. Leksikon ini berasal dari bahasa Melayu Jambi yang biasa digunakan oleh masyarakat secara umum. Dari tiga dusun yang diteliti, semua dusun mengenal istilah ini juga menggunakan leksikon motong dalam kesehariannya. Leksikon ini lebih bersifat umum bila dibandingkan dengan leksikon mupul maupun ngudun.

\section{leksikon nyadap}


Leksikon nyadap berasal dari kata sadap yang bermakna 'mengambil air dari pohon dengan menoreh kulit pohon'. Leksikon nyadap umumnya digunakan oleh masyarakat yang berasal dari Jawa. Tidak semua daerah menggunakan leksikon ini, hanya sebagian kecil kelompok masyarakat di Dusun Sungai Kayu Batu. Meskipun penggunaannya terbatas, namun masyarakat antar desa saling memahami. Leksikon nyadap penggunaannya hampir sama dengan leksikon motong maupun leksikon ngudun.

\section{leksikon mbankit}

Leksikon mbangkit berasal dari gabungan dua kata meN + bangkit-> mbangkit yang mengalami proses afiksasi. Leksikon mbangkit memiliki makna leksikal yakni 'mengangkat'. Leksikon mbangkit merupakan proses yang dilakukan petani dengan tujuan untuk mengambil dan mengumpulkan kudun (getah pohon karet yang sudah membeku di dalam tempat penampungan) yang berada di pohon karet. Untuk di daerah Simpang Babeko, mbangkit biasanya dilakukan 1 x kali per dua minggu atau kira-kita kudun yang berada di pohon sudah dianggap banyak. Ada dua tipe ngudun yang ditemukan di lapangan, pertama dengan tujuan mengumpulkan kudun tersebut lalu dimasak dan diberikan obat di dalam suatu tempat (biasanya disebut bak). Ada pula yang hanya mengumpulkan kudun di dalam karung tanpa dimasak dan tidak juga diberikan obat.

\section{leksikon mbangkit kudun}

Leksikon mbankit kudun merupakan tindakan khusus yang dilakukan petani untuk mengambil kudun di kebun tanpa perlu dimasak. Kudun tersebut dikumpulkan lalu dimasukkan ke dalam karung kemudian dibawa pulang. Kegiatan mbangkit kudun hanya dikususkan pada tindakan yang hanya berkaitan dengan kudun, berbeda dengan leksikon mbangkit yang penggunaanya lebih umum.

\section{leksikon ngambek getah}

Setelah mbangkit dilaksanakan, biasanya kegiatan selanjutnya yaitu ngambek getah 'mengambil getah'. Leksikon ngambek getah berasal dari kata bahasa Melayu Jambi. Getah yang dimaksud di sini merupakan kudun yang sudah 
dimasak di dalam suatu tempat bernama bak. Getah yang sudah dicetak dan beku, lalu diangkut pulang ke rumah atau langsung dijual ke toke, proses ini yang disebut dengan ngembek getah.

\section{2) Tindakan Membersihkan}

Berkaitan dengan tindakan membersihkan ini ditemukan 3 (tiga) leksikon, leksikon mancah, leksikon mancah lorong, dan leksikon nebeh yang lazim dilakukan masyarakat desa Simpang Babeko dengan tujuan kebun yang memiliki tanaman karet ataupun yang lain menjadi bersih. Leksikon yang ditemukan juga bervariasi tergantung hal apa yang dilakukan.

\section{leksikon mancah}

Leksikon mancah berasal dari kata pancah merupakan kata yang berasal dari bahasa Melayu Jambi yang bermakna ‘bersih atau tebas'. Mancah merupakan gabungan dari prefiks MaN + pancah -> mancah. Leksikon mancah merupakan tindakan yang dilakukan masyarakat untuk membersihkan kebun, baik secara keseluruhan maupun sebagian. Kegiatan mancah ini lazimnya menggunakan parang maupun dengan menggunakan mesin rumput. Agar kebun bersih dari gulma, rumput-rumput maupun batang-batang kecil yang menggangu tanaman karet.

\section{leksikon mancah lorong}

Leksikon mancah lorong merupakan tindakan yang lebih khusus pada kegiatan membersihkan lorong. Lorong adalah jalan antara batang ke batang pohon karet, lorong ini biasanya dibersihkan agar kegiatan menyadap karet di kebun lebih mudah. Leksikon mancah lorong merupakan gabungan dari kata mancah + lorong. Leksikon macah lorong hanya digunakan ketika kegiatannya hanya berkutat membersihkan lorong saja.

\section{leksikon nebeh}

Leksikon nebeh merupakan kata yang berasal dari bahasa Melayu Jambi yang bermakna 'tebas'. Leksikon nebeh merupakan tindakan yang hampir mirip dengan leksikon mancah, namun bedanya adalah leksikon nebeh umum digunakan oleh masyarakat pribumi sedangkan leksikon mancah umum digunakan 
oleh masyarakat Jawa. Temuan di lapangan bahwa leksikon nebeh ini digunakan di Desa Simpang Babeko sedangkan leksikon mancah dan leksikon mancah lorong ditemukan di Dusun Nyiur Gading dan Dusun Sungai Kayu Batu.

\section{3) Tindakan Memberi}

Berkaitan dengan leksikon tindakan yang bermedan makna tindakan memberi ditemukan 3 (tiga) leksikon, leksikon ne-es, leksikon mupuk, dan leksikon nyuko. Leksikon tersebut akan dijelaskan sebagai berikut:

\section{leksikon ne-es}

Leksikon ne-es merupakan leksikon yang bermakna leksikal 'memberikan pupuk'. Leksikon ini berasal dari kata TSP (triple super phosphate) atau sebuah merek pupuk yang biasa digunakan untuk tanaman. Kata ini mengalami perubahan dari TSP menjadi ne-es 'memberikan TSP'. Pada masyarakat Desa Simpang Babeko leksikon ini umum digunakan saat getah yang sudah terkumpul di penampungan yang berbentuk tempurung kelapa diberi pupuk. Tujuan diberikan pupuk ini agar getah tersebut cepat membeku.

\section{leksikon mupuk}

Leksikon mupuk merupakan leksikon yang berasal dari kata pupuk. Leksikon mupuk mengacu pada tindakan aktivitas memberikan suatu cairan pada getah karet. Leksikon ini penggunaan dalam masyarakat mirip dengan leksikon ne-es, namun sifatnya lebih umum, pemberian pupuk ini yang berasal dari pupuk TSP maupun yang berasal dari cuka (Cuka 61).

\section{leksikon nyuko}

Leksikon nyuko merupakan leksikon yang bermakna leksikal 'memberikan cuka' atau memberikan cairan tertentu dengan tujuan agar getah karet lebih cepat membeku. Leksikon nyuko berasal dari kata memberi cuko dalam bahasa Melayu Jambi.

Ketika getah karet yang sudah terkumpul di tempat penampungan, perlu diberikan cuka yang berasal dari cuka 61 (nama salah satu merek cuka getah karet). Leksikon tersebut penggunaanya dikhususkan pada tindakan aktivitas yang menggunakan cuka dengan bahan dasar cuka 61, tidak digunakan dengan bahan 
dasar pupuk TSP. Cuka 61 yang dibeli, kemudian ditambahkan air biasa sesuai dengan takaran tertentu agar takarannya tepat. Penggunaan cuka 61 lebih mudah karena hanya mencampurkan saja, berbeda dengan penggunaan pupuk TSP, yang harus menunggu minimal 3 hari agar larut di dalam air.

Berdasarkan penggunaan leksikon ne-es, mupuk, dan nyuko tersebut penggunaan di masyarakat Desa Simpang Babeko cukup beragam. Ada kelompok masyarakat yang hanya menggunakan leksikon ne-es di beberapa tempat saja, sedangkan leksikon nyuko umum digunakan oleh masyarakat pribumi. Namun, leksikon mupuk umum digunakan pada kelompok masyarakat Jawa sajaa yang ditemukan dalam tiga dusun di Desa Simpang Babeko. Akan tetapi, penggunaan ketiga leksikon tersebut kadang dipertukarkan disebakan oleh lawan bicara berasal dari suku apa. Misalkan masyarakat pribumi biasa menggunakan leksikon nyuko, ketika bertemu orang jawa, agar saling memahami digunakan leksikon mupuk.

\section{4) Tindakan Mengambil}

Dalam masyarakat Desa Simpang Babeko, dikenal dengan dua istilah yang paling umum untuk menyatakan tindakan mengambil getah dari pohon karet. Dua istilah tersebut hanya ditemukan 2 (dua) yaitu nyadap dan motong. Kedua leksikon ini disebut dengan leksikon tindakan yang berkaitan dengan mengambil getah karet.

\section{leksikon motong dan nyadap}

Leksikon motong berasal dari kata bahasa Melayu Jambi putong yang bermakna 'potong'. Leksikon ini bermakna tindakan yang dilakukan oleh petani karet untuk menyadap atau mendapatkan getah dari pohon karet dengan menggunakan pisau khusus yang disebut dengan pisau potong. Begitu juga dengan leksikon nyadap memiliki makna yang hampir sama dengan leksikon motong, namun bedanya berasal dari bahasa Jawa nyadap yang berarti 'sadap'. Dua leksion tersebut berbeda penggunaan dalam masyarakat Desa Simpang Babeko. Leksikon motong atau mutong biasa digunakan oleh masyarakat pribumi sedangkan leksikon nyadap digunakan masyarakat Jawa atau masyarakat lain yang berasal dari luar Jambi. 


\section{5) Tindakan Berpindah Tempat}

Dalam kaitannya dengan berpindah tempat, hanya ditemukan 1 (satu) leksikon saja yaitu leksikon nimbal. Leksikon nimbal berasal dari bahasa Indonesia timbal-balik yang telah mengalami peleburan pada kata dasarnya sehingga menjadi nimbal. Leksikon nimbal merupakan tindakan yang dilakukan oleh petani karet untuk menjelaskan tindakan berpindah tempat dari kebun yang satu ke kebun yang lain setelah pekerjaan di salah satu kebun selesai. Leksikon ini secara umum digunakan di seleruh dusun yang ada di Desa Simpang Babeko.

\section{Simpulan}

Berdasarkan pemaparan tersebut dapat ditarik suatu kesimpulan bahwa variasi dalam bidang leksikon sangat umum terjadi di masyarakat. Hal terjadi dikarekanakan adanya percampuran budaya antar masyarakat. Leksikon tindakan yang digunakan oleh petani karet di Desa Simpang Babeko misalnya, mengalami proses pencampuran dari berbagai bahasa terutama bahasa Melayu Jambi dan bahasa Jawa yang dipakai oleh masyarakatnya.

Dari penelitian ini ditemukan sebanyak 16 (enam belas) leksikon yang berupa tindakan yang digunakan oleh petani karet di Desa Simpang Babeko. Dari 16 (enam belas) leksikon tersebut, mendapatkan lima jenis makna tindakan yang berkaitan dengan tindakan aktivitas petani karet yaitu 1) tindakan mengambil (tujuh leksikon), dengan data leksikon mupul, leksikon ngudun, leksikon mbankit, leksikon mbangkit kudun, leksikon ngambek getah, leksikon motong, dan leksikon nyadap, 2) tindakan membersihkan (tiga leksikon), dengan data leksikon mancah, leksikon mancah lorong, dan leksikon nebeh. 3) tindakan memberi (tiga leksikon), dengan data leksikon ne-es, leksikon mupuk, dan leksikon nyuko. 4) tindakan mengambil (dua leksikon), dengan data leksikon motong dan leksikon nyadap. 5) Tindakan Berpindah Tempat (satu leksikon), dengan data leksikon nimbal. Semua tindakan tersebut mengacu pada kegiatan yang lazim digunakan oleh masyarakat petani karet. 


\section{Daftar Pustaka}

Chaer, Abdul. 2007. Leksikologi \& Leksikografi Indonesia. Jakarta: Penerbit Rineka Cipta

Kridalaksana, Harimurti. 2001. Kamus Linguistik. Ed. ke-3. Jakarta: Penerbit PT Gramedia Pustaka Utama.

Kusumawati, Siska. 2016. "Leksikon Budaya Dalam Ungkapan Peribahasa Sunda (Kajian Antropolinguistik)”. LOKABASA Vol.7, No.1, April 2016 hal. 87-93. Diunduh dari https://ejournal.upi.edu/index.php/lokabasa/article/view/3421.

Sitinjak, Hertina. 2018. "Leksikon Verbal dan Umpasa dalam Tari Tortor Sawan: Kajian Antropolinguistik”. Skripsi Prodi Sasindo Universitas Sumatera Utara.

Sudaryanto. 1988. Metode Linguistik (Bagian Pertama: Ke Arah Memahami Metode Linguistik). Cetakan ke 2. Yogyakarta: Gadjah Mada University Press.

Sudaryanto. 1993. Metode dan Aneka Teknik Analisis Bahasa. Yogyakarta: Duta Wacana University Press.

Yusuf, Suhendra. 1995. Leksikon Sastra. Bandung: Penerbit Mandar Maju. 